DOI: https://doi.org/10.32839/2304-5809/2020-5-81-80

UDC $378.147 .88+81-13$

Morentsova Alla

National Technical University of Ukraine "Igor Sikorsky Kyiv Polytechnic Institute"

\title{
EXTENSIVE ENGLISH READING FOR DEVELOPING ACADEMIC READING SKILLS
}

Summary. This article deals with the possibilities of implementing extensive reading into the language courses of universities to develop academic reading skills. Academic reading and writing are, in many ways, new to students upon entering university. The task of language trainers and teachers is to find creative, relevant and useful ways to show students what the skills and practices are in relation to extensive reading and academic reading and how to use. In addition to course assignments, a substantial amount of academic reading is required in order to write high-quality research papers. A trained reader has a systematic technique for finding the most information in the least amount of time. The author confirms the positive results of using imaginative literature in the educational process, in particular, adapted books in English. The article concludes that a meaningful choice of fiction and non-fiction literature recommended for students for extensive reading is an important task of a modern English teacher. Studying existing adapted English-language books for the purpose of selection and use in the learning process is a prospective area.

Keywords: extensive reading, academic reading, academic skills, foreign language, higher education.

Моренцова А.В.

Національний технічний університет України «Київський політехнічний інститут імені Ігоря Сікорського»

\section{ЗАСТОСУВАННЯ ЕКСТЕНСИВНОГО ЧИТАННЯ АНГЛІЙСЬКОЮ МОВОЮ ДЛЯ РОЗВИТКУ НАВИЧОК АКАДЕМІЧНОГО ЧИТАННЯ}

Анотація. У статті розглядаються можливості використання екстенсивного читання англійською мовою для набуття та розвитку навичок академічного читання у немовних вищих навчальних закладах з урахуванням зростання ролі англійської мови як інструменту наукової комунікації. Автором з'ясовано, що екстенсивне читання розширюе освітні можливості в процесі вивчення студентами англійської мови. Підтверджено поліпшення навичок читання і письма, зростання словникового запасу, а також підвищення самооцінки і мотивації студентів при впровадженні екстенсивного читання у навчальний процес. Автором запропоновано використовувати в процесі навчання адаптовані книги на англійській мові. Зважаючи на позитивний вплив використання англомовного художнього тексту в процесі вивчення англійської мови як іноземної, пропонується застосування відповідної художньої літератури, яка окрім вивчення мови сприятиме розвитку світогляду і країнознавчої компетенції студентів. Зазначається важливість обрання текстів, особливо на початку програми з екстенсивного читання, таким чином, щоб книги були цікаві для студентів та не надто перевищували їх здатності до читання на англійській мові. Обірунтовуеться, що читання адаптованих книг може застосовуватись на початкових етапах формування і в процесі розвитку академічної грамотності майбутніх фахівців. Зауважено, що належна підготовка викладачів для викладання іноземної мови студентам може вирішити більшість проблем, пов'язаних з читанням та вибором адаптованих книг. На основі дослідженого матеріалу надаються загальні рекомендації щодо поєднання екстенсивного і інтенсивного читання. Також констатуеться, що читання науково-популярних журналів, призначених для широкої аудиторії, допоможе студентам-початківцям оволодіти науковою лексикою, зокрема, базовою технічною термінологією. Автор вважає доцільним корегування підходу до роботи з англомовними джерелами, при якому студенти матимуть можливість не тільки працювати з текстами на предмет їх перекладу, аналізу лексики, граматики та фразеології, але навчатимуться безпосередньому використанню текстів в академічних цілях. Ключові слова: екстенсивне читання, академічне читання, академічна підготовка, іноземна мова, вища освіта.

Droblem statement. In view of internationPatization of education, foreign-language communication competence became the cornerstone of academic and professional mobility of future specialists. Considering the concept of lifetime education, teaching foreign languages becomes more and more complex, necessitating identification, application and improvement of numerous various approaches and instruments. Among the new challenges which modern education has to face are formation and development of academic literacy of future specialists, considering the growing role of the English language as an instrument of scientific communication. When teaching English at higher education institutions of nonlinguistic specialization, attention must be devoted to development in students of academic reading and writing skills.
Analysis of the latest studies and publications. It is a well-known fact that reading helps develop a literate speech, making speech lexically full and correct. Numerous scholars devoted their works to reading as an important activity in the course of teaching a foreign language and to reading methods (Kachalov M.O., Kostylev P.M., Bondareva Y.P., Chystiakova H.V., Stepanov O.O., Firsova A.M., Kartseva E.V., Matvieiev S.O., Popova T.V., Lytaieva M.O., Talalakina Y.V., Oleinik A.N., Nuzha I.V., Shchemeleva I.Y. and other). M.O. Lytaieva and Y.V. Talalakina studied such a phenomenon in modern pedagogy as academic ability, in particular, academic reading [1]. Teaching academic reading is an important aspect of preparing specialists at higher education institutions. Numerous difficulties arise when developing aca- 
demic reading skills and the related academic writing skills. To achieve the goals of academic reading by beginner researchers, P.M. Kostylev defines the following reading strategies: inquisitive, concise, in-depth and contextual reading [2].

Highlighting the previously unsolved parts of a general problem. The problem of teaching full-fledged, productive reading with imperfect mastery of a foreign language climbs higher and higher on the agenda. Gaining cognitive communication ability and the skills of conscious reading with clear understanding of the content is an important objective for students learning English. A situation can often be observed, when the teaching of reading becomes a work on texts, i.e., reading aloud, formulating questions and answers, written translation, narration, etc. In the course of teaching a foreign language, insufficient attention is devoted to reading as a form of language activity. Teaching future specialists the skills of academic reading and writing is also virtually nonexistent.

Formulation of goals. This article considers the possibility of using extensive reading in English, particularly adapted works of fiction, in the course of learning a foreign language at higher education institutions of technical specialization. Considering the already published studies, the purpose of this article is to analyze and substantiate the use of extensive reading in English to gain and enhance academic reading skills. In this regard, it seems prudent to adjust the approach to the work with English-language sources by shifting emphasis from the translation of a foreign-language text to the immediate use of that text for academic purposes.

Description of study. The need to change the stereotyped perception of English-language literature by students and to teach them adequate approaches to reading (in particular, to teach them academic literacy) is a contemporary objective in preparation of modern specialists [4]. Professionally-oriented textual educational materials are used, as a rule, in the course of learning a foreign language at higher education institutions of technical specialization. English-language works of popular science and publications about the latest technologies adapted for reading by beginner students, etc., are virtually unavailable. Therefore, beginner students not yet proficient in English enough to receive satisfaction from what they read encounter certain difficulties with reading and understanding what they read. In insufficiently motivated students, these difficulties may lower their motivation even more [3]. As follows from the studies by various authors, limited cognitive abilities of readers do not allow them to find and highlight all potentially interesting ideas in the text, especially in the conditions of rapidly growing number of scientific publications [6].

In order to avoid this situation, the author of this article draws attention to adapted English-language works of fiction, which could be successfully used to get students interested and to raise their motivation. These books would be helpful for comprehensive development of students, stimulating in them active self-cognition and research activity [4]. An adequate selection of books can reveal country-specific linguistic aspects to students, because they can learn from books about social and cultural order of a foreign-language society. In addition, independent reading in English helps develop an esthetic taste and independent work skills in students [4].

Positive features of a fiction text include orientation toward the person's general cognition and absence of the need for specialized background knowledge. The compositional structure of a work of fiction continues to draw interest during the entire process of reading. The meaning of certain words becomes clear from the context. There is an option of choosing the beginner, intermediate or advanced level of complexity of adapted English-language books. Adapted English-language books are best suitable for extensive reading, i.e., reading of the largest possible number of simple books.

The author states that extensive reading helps enhance academic reading and writing skills in students. We know that the components of academic reading include the ability to understand specifics of the text's logical construct, the ability to retrieve information of general or more private nature from the text, the ability to guess correctly the meaning of unfamiliar words from the context [7]. According to definition, academic reading represents a separate form of reading aimed at extracting information from the texts of popular science and scientific language styles, analyzing the structure of a scientific text, and eventually, creating a secondary text (abstract, synopsis, etc.) [1].

The results of a study by M.A. Nhapulo, E. Simon and M. Van Herreweghe, described in their article, convincingly prove "that extensive general reading transfers to academic reading skills" [5]. 30 university students participated in this study, which continued for four months. After implementing an extensive reading program, an increasing reading speed and better understanding of the text they read were observed among the students. However, motivation of students for reading increased very insignificantly, if at all [5].

A study of students' motivation for, and attitude toward, extensive and intensive reading, performed by Deniz Erguvan, is also worth noting [8]. Based on the results gathered for 54 students, the scholar asserts that students are not always able to assess and synthesize information received during reading, and are almost never interested in reading for pleasure. However, if students select a text themselves, it increases their motivation and confidence, and as a result, develops a more positive attitude toward reading and learning the language. Erguvan even says that "there is a global reluctance to read printed materials" [8, p. 148]. She concludes that in order to encourage students to read, reading must be an obligatory component of the course. Deniz Erguvan generalizes the opinion that both extensive and intensive approaches must be used as mutually supplementing [8].

Therefore, based on the results of studies, the author suggests using adapted English-language works of fiction both for in-class and independent work of students. In order for extensive reading of these works to bring the most benefits, it is recommended to start with those English-language books which the students have already read translated in their native language. This approach must increase motivation of readers from the very beginning and keep them interested in continuing to read. Reading adapted English-language literature can be 
regarded, with certain assumption, as extensive reading, which in turn, helps enhance academic reading skills. The next step in mastering the reading of specialized scientific and technical literature could be reading English-language popular science magazines for a broad audience. As a rule, magazines of this type publish texts about science and technologies in an interesting and comprehensible form using the latest terms and concepts. Reading popular science magazines will help students in mastering scientific lexicon, in particular, basic technical terminology.

Conclusions drawn from this study, and further development prospects. This article reviewed the advantages of using extensive reading in English to gain and enhance academic reading skills. Academic reading and writing are, in many ways, new to students upon entering university. The task of language trainers and teachers is to find creative, relevant and useful ways to show students what the skills and practices are in relation to extensive reading and academic reading and how to use. Considering the positive effect from using English-language fiction texts in the course of learning English as a foreign language, it is proposed to use works of fiction (in particular, adapted English-language books) in the learning process for linguistic and esthetic development of students and to develop academic reading and writing skills in students. Studying existing adapted English-language books for the purpose of selection and use in the learning process is a prospective area.

\section{References:}

1. Lytaeva, M.A., \& Talalakina, E.V. (2011). Academic skills: sushchnost, model, praktika [Academic skills: essence, model, practice]. Voprosy obrazovaniia [Educational Issues], vol. 4, pp. 178-201. (in Russian)

2. Kostylev, P.N. (2015). Akademicheskoe chtenie v gumanitarnykh naukakh [Academic Reading in the Humanities]. Elektronnoe nauchnoe izdanie Al'manakh Prostranstvo $i$ Vremya: "Prostranstvo $i$ vremya teksta" [Electronic Scientific Edition Almanac Space and Time: "Space and Time of Text”', vol. 10.1 (5). (in Russian)

3. Merritt, A. (2013). What motivates us to learn foreign languages? The Telegraph (28.02.2013). Available at: https://www.telegraph.co.uk/education/educationopinion/9900074/What-motivates-us-to-learn-foreignlanguages.html (accessed: 25 May 2020).

4. Morentsova, A.V. (2020). Samostiine ekstensyvne chytannia adaptovanykh knyh anhliiskoiu movoiu u nemovnykh vyshchykh navchalnykh zakladakh [Individual extensive reading of adapted books in english in non-linguistic universities]. Molodyi vchenyi [Young scientist], vol. 4. (in Ukrainian)

5. Nhapulo, M.A., Simon, E. \& Van Herreweghe, M. (2017). Enhancing academic reading skills through extensive reading. Southern African Linguistics and Applied Language Studies, vol. 35(1), pp. 17-40.

6. Oleinik, A.N., Kirdina, S.G., Popova, I.P. \& Shatalova, T.Y. (2013). Akademicheskoe chtenie: predely ponimaniia i interpretatcii [Academic Reading: The Limits of Understanding and Interpretation]. Politicheskaia kontceptologiia: zhurnal metadistciplinarnykh issledovanii [Political Conceptology: Journal of Metadisciplinary Research], vol. 4, pp. 251-265. (in Russian)

7. Popova, T.V. (2018). Akademicheskoe chtenie kak sredstvo formirovaniia kommunikativnoi kompetentcii studentov [Academic reading as a means of forming students'ommunicative competence]. Azimut nauchnykh issledovanii: pedagogika i psikhologiia [Azimuth of Scientific Research: Pedagogy and Psychology]. T. 7. Vol. 3(24), pp. 188-192. (in Russian)

8. Erguvan, D. (2016). Students' Attitudes towards Extensive and Intensive Reading and Instructors' Motivational Strategies. Arab World English Journal, vol. 7(2), pp. 136-150.

\section{Список літератури:}

1. Лытаева М.А., Талалакина Е.В. Academic skills: сущность, модель, практика. Вопросы образования. 2011. № 4. C. 178-201.

2. Костылев П.Н. Академическое чтение в гуманитарных науках. Электронное научное издание Альланах Пространство и Время. 2015. № 10(1). С. 5.

3. Merritt A. What motivates us to learn foreign languages? The Telegraph (28.02.2013). URL: https://www.telegraph.co.uk/education/educationopinion/9900074/What-motivates-us-to-learn-foreignlanguages.html (дата звернення: 25.05.2020).

4. Моренцова А.В. Самостійне екстенсивне читання адаптованих книг англійською мовою у немовних вищих навчальних закладах. Молодий вчений. 2020. № 4.

5. Nhapulo M.A., Simon E. \& Van Herreweghe M. Enhancing academic reading skills through extensive reading. Southern African Linguistics and Applied Language Studies. 2017. 35(1), pp. 17-40.

6. Олейник А.Н., Кирдина С.Г., Попова И.П., Шаталова Т.Ю. Академическое чтение: пределы понимания и интерпретации. Политическая кониептология: журнал метадисииплинарных исследований. 2013. № 4. C. 251-265.

7. Попова Т.В. Академическое чтение как средство формирования коммуникативной компетенции студентов. Азимут научных исследований: педагогика и психология. 2018. Т. 7, № 3(24). С. 188-192.

8. Erguvan D. Students' Attitudes towards Extensive and Intensive Reading and Instructors' Motivational Strategies. Arab World English Journal. 2016. Vol. 7(2), pp. 136-150. 